\title{
ANALISIS PENGARUH WORKING CAPITAL TURNOVER, FIRM SIZE, GROWTH OPPORTUNITY DAN PROFITABILITAS TERHADAP STRUKTUR MODAL PERUSAHAAN PT FAST FOOD INDONESIA TBK
}

\author{
Emma Lilianti \\ Fakultas Ekonomi Universitas PGRI Palembang \\ Email: emmaliliantiok@gmail.com \\ Reva Maria Valianti \\ Fakultas Ekonomi Universitas PGRI Palembang \\ Email: revavallianti@univpgri-palembang.ac.id
}

DOI. 10.35908/jeg.v4i2.752

Received: May 20, 2019, Revised: June 20, 2019, Accepted: July 01, 2019

\begin{abstract}
This research purpose to analyze the effect of Working Capital Turnover, Firm Size, Growth Opportunity, Profitability on the Capital Structure of the Company PT Fast Food Indonesia Tbk. The year of observation for 5 years is 2014 at 2018, with the object of PT. Fast Food Indonesia Tbk. The method of analysis uses quantitative descriptive method. The results showed that the working capital turnover of the company> 3 times the efficiency of the company's working capital turnover in $2014 \mathrm{~d}$. 2018 efficiency. The size of a good company can be seen from the company's total asset value quite well. Total assets of PT. Fast Food continues to experience a significant increase every year. Growth opportunity PT. Fast Food has decreased every year even though sales have increased. This shows the low growth opportunity of the company can mean that the company does not have flexibility in investing optimally because the company manager will take action to transfer wealth from creditors to investors, so that the company is expected to have low debt. The level of profitability can be measured from the level of the company's fluctuating profits and significantly increased in 2018. In 2014 to 2015 decreased by $4.7 \%$, then in 2016 increased by $3.9 \%$ and in 2016 decreased by $1.37 \%$ and in 2018 experienced a drastic increase in profit of $5.55 \%$.
\end{abstract}

Keywords: Working Capital Turnover, Firm Size, Growth Opportunity, Profitability, Capital Structure

\begin{abstract}
ABSTRAK
Penelitian ini bertujuan untuk menganalisis pengaruh Working Capital Turnover, Firm Size, Growth Opportunity, Profitabilitas terhadap Struktur Modal Perusahaan PT Fast Food Indonesia Tbk. Tahun pengamatan selama 5 tahun yaitu 2014 s.d 2018, dengan objek PT. Fast Food Indonesia Tbk. Metode analisis menggunakan metode deskriftif kuantitatif. Hasil penelitian menunjukkan perputaran modal kerja perusahaan > 3 kali maka tingkat efisiensi perputaran modal kerja perusahaan tahun 2014 s.d tahun 2018 efisiensi. Size perusahaan baik dapat dilihat dari nilai total aset perusahaan cukup baik. Total aset PT. Fast Food terus mengalami peningkatan signifikan tiap tahunnya. Growth opportunity PT. Fast Food mengalami penurunan tiap tahunnya meskipun penjualan mengalami peningkatan. Hal ini menunjukkan rendahnya growth opportunity perusahaan dapat bermakna bahwa perusahaan tersebut tidak memiliki fleksiblilitas dalam melakukan investasi secara optimal yang dikarenakan manajer perusahaan akan melakukan tindakan pengalihan kemakmuran dari kreditur kepada investor, sehingga diharapkan perusahaan tersebut memiliki utang yang rendah. Tingkat profitabilitas dapat diukur dari tingkat laba perusahaan cukup fluktuatif dan meningkat signifikan pada tahun 2018. Tahun 2014 ke 2015 menurun sebesar 4,7\%, selanjutnya pada tahun 2016 meningkat sebesar 3,9\%
\end{abstract}


dan tahun 2016 menurun sebesar 1,37\% dan tahun 2018 mengalami peningkatan laba drastis sebesar $5,55 \%$.

Kata Kunci: Working Capital Turnover, Firm Size, Growth Opportunity, Profitabilitas,Struktur Modal

\section{Pendahuluan}

Besarnya laba yang diperoleh bukanlah satu-satunya tolak ukur keberhasilan sebuah perusahaan, namun lebih ditekankan pada kemampuan perusahaan dalam mengelola modal kerja yang ada untuk menghasilkan profit. Modal kerja diperlukan untuk memastikan perusahaan dapat melanjutkan kegiatan operasionalnya sehari-hari. Perusahaan memerlukan modal kerja yang akan digunakan untuk keperluan investasi membeli atau membiayai aset tetap dan bersifat jangka panjang yang dapat digunakan secara berulang-ulang, seperti pembelian tanah, bangunan, mesin, kendaraan dan aset tetap lainnya. Modal kerja menurut Halim (2015:159) terdiri dari beberapa elemen yaitu kas, piutang dan persediaan. Perputaran modal kerja pada penelitian ini dihitung dengan rumus perputaran modal kerja sama dengan penjualan dibagi modal kerja bersih.

Jumingan (2011:132) menyatakan "untuk menguji efisiensi penggunaan modal kerja penganalisis dapat menggunakan perputaran modal kerja (working capital turn over), yakni rasio antara penjualan dengan modal kerja". Efektifitas yang dimaksud adalah cepat lambatnya periode perputaran modal kerja yang terjadi. Modal kerja merupakan modal yang selalu berputar secaraterus menerus dan setiap perputaran akan menghasilkan aliran pendapatan (current income) yang dapat berguna bagi perusahaan (Jumingan, 2011:67). Modal kerja yang terlalu besar atau berlebih akan mengakibatkan dana yang tersedia menjadi tidak produktif karena adanya dana yang menganggur. Sebaliknya, modal kerja yang terlalu kecil juga akan mengganggu jalannya operasi perusahaan dan mengakibatkan kondisi illikuid, yaitu kondisi dimana perusahaan kesulitan untuk melunasi utang jangka pendek yang telah jatuh tempo. Konsep modal kerja terdiri dari konsep kuantitatif, kualitatif dan fungsional Riyanto (2013:57). Pada konsep kuantitatif modal kerja terdiri dari aktiva lancar dan disebut modal kerja bruto (gross working capital). Pada konsep kualitatif modal kerja terdiri dari aktiva lancar dan utang lancar dan disebut modal kerja bersih (networking capital). Pada konsep fungsional terdapat dana yang menghasilkan pendapatan pada periode tersebut (current income) dan dana untuk menghasilkan pendapatan pada periode yang akan datang (future income)

Keberhasilan perusahaan dalam menghasilkan laba dapat dipengaruhi atau didukung oleh ukuran perusahaan. Ukuran perusahaan (Size Firm) menurut Sartono (2010:249) "Perusahaan besar yang sudah well estabilished akan lebih mudah memperoleh modal di pasar modal dibanding dengan perusahaan kecil. Kemudahan akses tersebut berarti perusahaan besar memiliki fleksibilitas yang lebih besar. Semakin tinggi nilai ukuran perusahaan maka makin tingi profitabilitas peerusahaan. Ukuran perusahaan dapat digunakan untuk menilai keadaan suatu perusahaan. Ukuran perushaan menjadi cerminan total dari asset yang dimiliki suatu perusahaan. Pada umumnya perusahaan berukuran besar mempunyai berbagai kelebihan dibandingkan perusahaan yang berukuran kecil. Semakin besar ukuran atau 
skala perusahaan maka akan semakin mudah pula perusahaan memperoleh sumber pendanaan baik bersifat internal ataupun eksternal. Menurut Setiawan (2009), perusahaan berukuran besar mampu berproduksi pada skala ekonomis, namun memperoleh potongan harga beli bahan baku, lebih baik dalam mengelola piutang dan mempunyai akses yang besar ke sumber-sumber dana untuk membiayai investasinya dibandingkan perusahaan kecil.

Menurut Brigham dan Houston (2011: 52) peluang tumbuh merupakan kesempatan suatu perusahaan untuk tumbuh di masa yang akan datang. Perusahaan-perusahaan yang memiliki prospek pertumbuhan tinggi cenderung memilih saham sebagai alternatif pendanaan, saham juga dapat meningkatkan profitabilitas perusahaan.

Profitabilitas merupakan kemampuan suatu perusahaan untuk mendapatkan laba (keuntungan) dalam suatu periode tertentu. Pengertian yang disampaikan oleh Husnan (2011) bahwa profitabilitas alah kemampuan suatu perusahaan dalam menghasilkan keunutungan (profit) pada tingkat penjualan, asset perusahaan dalam menghasilkan keuntungan (profit) pada tingkat penjualan, asset dan modal saham tertentu. Meningkatnya profitabilitas yang dicapai perusahaan akan meningkatkan harapan investor untuk memperoleh pendapatan dividen yang tinggi pula serta kinerja keuangan perusahaan. Semakin besar profotabilitas perusahaan maka semakin besar pula laba yang diperoleh dan penilaian kinerja semakin besar. Semakin baik rasio profitabilitas maka semakin baik menggambarkan kemampuan tingginya perolehan keuntungan perusahaan.
Utari (2014:63) mengatakan bahwa profitabilitas adalah kemampuan perusahaan dalam memperoleh laba. Laba dapat digunakan untuk mengukur keberhasilan akvitas yang dilakukan oleh perusahaan dengan menggunakan rasio profitabilitas. Rasio profitabilitas yang umumnya digunakan untuk mengukur kemampuan perusahaan dalam menghasilkan laba adalah Profit Margin, Return On Asset (ROA), dan Return On Equity (ROE). Hanafi $(2014,24)$ menyatakan Return on assets (ROA) merupakan salah satu rasio profitabilitas yang dapat mengukur kemampuan perusahaan dalam menghasilkan laba dari aktiva yang digunakan. ROA mampu mengukur kemampuan perusahaan menghasilkan keuntungan pada masa lampau untuk kemudian diproyeksikan di masa yang akan datang. Return On Asset (ROA) adalah kemampuan perusahaan menghasilkan laba berdasarkan tingkat aset tertentu.

Struktur merupakan urat nadi jalannya perusahaan, perusahaan yang memiliki struktur modal berupa utang yang tinggi, berpotensi untuk tidak dapat melunasi beban bunga dan pokok pinjaman. Hal tersebut berpotensi timbulnya pandangan yang negatif di kalangan investor. Perusahaan tersebut diduga oleh investor sedang mengalami kesulitan keuangan (financial distress), sehingga investor tidak tertarik untuk menanamkan modalnya. Di pihak lain, perusahaan yang mengalami struktur modal berupa utang yang rendah berpotensi untuk mengeluarkan saham baru.

PT Fast Food Indonesia Tbk Sebagai pemegang hak waralaba tunggal untuk merek KFC di Indonesia, pembukaan gerai-gerai di Jakarta dan ekspansi hingga ke sejumlah kota besar lainnya di Indonesia antara lain Bandung, Palembang, Semarang, Surabaya, Medan, 
Makassar, dan Manado dan menyebar di seluruh Provinsi di Indonesia. Sukses membangun merek ini, menanamkan KFC dalam benak konsumennya sebagai merek waralaba cepat saji yang terkenal dan dominan di Indonesia. Pengalaman sukses dan peningkatan pertumbuhan yang berkelanjutan selama lebih dari 30 tahun, tidak diragukan lagi telah menjadikan merek KFC sebagai pemimpin pasar restoran cepat saji di negara ini. Ekspansi jaringan restoran terus diupayakan supaya bisa hadir dekat dengan konsumen. Berikut ini grafik laba bersih setelah pajak PT. Fast Food Indonesia, Tbk dapat dilihat pada gambar berikut ini:

\section{Gambar 1}

Laba PT. Fast Food Indonesia, Tbk Tahun 2014 s.d 2018 (dalam \%)

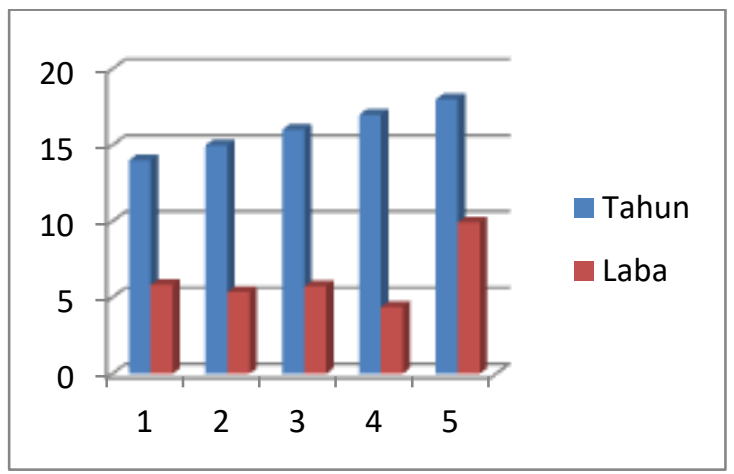

Pada gambar 1 dapat dilihat tingkat Laba perusahaan cukup fluktuatif dan meningkat signifikan pada tahun 2018. Tahun 2014 ke 2015 menurun sebesar 4,7\%, selanjutnya pada tahun 2016 meningkat sebesar 3,9\% dan tahun 2016 menurun sebesar 1,37\% dan tahun 2018 mengalami peningkatan laba drastis sebesar $5,55 \%$.

Dari grafik tingkat laba perusahaan peneliti ingin menganalisis pengaruh modal kerja dan ukuran perusahaan serta peluang tumbuh terhadap profitabilitas perusahaan
PT. Fast Food Indonesia Tbk pada tahun 2014 s.d 2018.

\section{Kajian Pustaka}

\section{Working Capital Turnover (WCT)}

Perputaran modal kerja (working capital turnover) merupakan indikator yang digunakan untuk mengukur seberapa efektif penggunaan modal kerja pada suatu perusahaan. Perputaran modal kerja dimulai ketika modal kerja diinvestasikan pada kegiatan usaha sampai kembali menjadi kas kembali. Rumus untuk menghitung perputaran modal kerja (working capital turnover) adalah sebagai berikut:

Working Capital Turnover

$$
=\frac{\text { Penjualan }}{\text { Aset Lancar - Utang Lancar }} \times 1
$$

(Jumingan, 2011:133)

\section{Ukuran Perusahaan (Size)}

Tolak ukur besar kecilnya perusahaan dengan melihat seberapa besar nilai dari total aset, ekuitas, atau penjualan suatu perusahaan disebut dengan ukuran perusahaan (Brigham dan Houston, 20011). Perusahaan kecil lebih sedikit melakukan diversifikasi usaha dari pada perusahaan besar. Oleh karena itu kemungkinan kegagalan dalam menjalankan usaha atau kebangkrutan akan lebih besar. Menurut Sawir (2005) ukuran perusahaan merupakan determinan dari struktur keuangan dalam hampir setiap studi untuk alasan yang berbeda.

SIZE $=$ Ln Total Aset 


\section{Peluang Tumbuh (Growth Opportunity)}

Growth opportunity disebut juga kesempatan suatu perusahaan untuk tumbuh di masa yang akan datang (Brigham dan Houston, 2011).

\section{Growth Opportunity $=$ \\ $\frac{\text { Sales } t-S a l e s t-1}{\text { Sales } t-1} \times 100 \%$}

\section{Profitabilitas}

Return On Assets dipakai untuk mengevaluasi apakah manajemen telah mendapat imbalan yang memadai (reasobable return) dari aset yang dikuasainya. Rasio ini merupakan ukuran yang berfaedah jika seseorang ingin mengevaluasi seberapa baik perusahaan telah memakai dananya. (Simamora, 2012:530). Berikut pengertian ROA:

1. Menurut Kasmir (2014:201), Return On Assets merupakan rasio yang menunjukkan hasil atas jumlah aktiva yang digunakan dalam perusahaan.

2. Menurut Fahmi (2012:98), Return On Assets melihat sejauh mana investasi yang telah ditanamkan mampu memberikan pengembalian keuntungan sesuai dengan yang diharapkan dan investasi tersebut sebenarnya sama dengan aset perusahaan yang ditanamkan atau ditempatkan.

3. Horne dan Wachowicz (2005:235), ROA mengukur efektivitas keseluruhan dalam menghasilkan laba melalui aktiva yang tersedia; daya untuk menghasilkan laba dari modal yang diinvestasikan.

4. Bambang Riyanto (2013:336) menyebut istilah ROA dengan Net Earning Power Ratio (Rate of Return on Investment / ROI) yaitu kemampuan dari modal yang diinvestasikan dalam keseluruhan aktiva untuk menghasilkan keuntungan neto. Keuntungan neto yang beliau maksud adalah keuntungan neto sesudah pajak.

5. Menurut Sawir (2005:18), Return On Assets (ROA) merupakan rasio yang digunakan untuk mengukur kemampuan manajemen perusahaan dalam memperoleh keuntungan (laba) secara keseluruhan. Semakin besar ROA suatu perusahaan, semakin besar pula tingkat keuntungan yang dicapai perusahaan dan semakin baik pula posisi perusahaan tersebut dari segi penggunaan asset.

Menurut Brigham dan Houston (2011), pengembalian atas total aktiva (ROA) dihitung dengan cara membandingkan laba bersih yang tersedia untuk pemegang saham biasa dengan total aktiva. Dirumuskan sebagai berikut:

$$
\text { ROA }=\frac{\text { Laba Setelah Pajak }}{\text { Total Aset }} \times 100 \%
$$

\section{Struktur Modal}

Modal adalah hak atau bagian yang dimiliki oleh para pemilik perusahaan dalam pos modal, surplus atau laba yang ditahan atau kelebihan aset yang dimiliki perusahaan terhadap seluruh utangnya (Munawir, 2013:19). Modal merupakan hak perusahaan yang timbul karena investasi yang dilakukan oleh pemilik maupun para investor sedangkan struktur modal adalah perimbangan atau perbandingan antara modal asing dengan modal sendiri. Struktur modal merupakan perbandingan antara total utang dengan total ekuitas.

$$
\text { DER }=\frac{\text { Total Utang }}{\text { Total Ekuitas }}
$$




$$
\begin{aligned}
\text { WCT } 2015 & =\frac{4.475 .001}{966.744-798.862} \times 1 \\
& =2261,48 \mathrm{kali}
\end{aligned}
$$

Data yang digunakan dalam penelitian ini yaitu data sekunder berupa data penjualan, aset lancar, utang lancar, total aset, dan laba yang diperoleh dari laporan keuangan dan laporan laba rugi perusahaan.

\section{Metode Analisis}

Penelitian ini menggunakan metode deskriptif kuantitatif yaitu metode penelitian dengan cara menghitung dan menganalisis data-data Working Capital Turnover, SIZE, Growth Opportunity, Profitabilitas dan Struktur Modal (DER).

\section{Objek dan Waktu Penelitian}

Penelitian dilakukan pada PT. Fast Food Indonesia, Tbk dengan masa pengamatan dilakukan untuk data tahun 2014 s.d 2018.

\section{Hasil dan Pembahasan}

\section{Analisis Working Capital Turnover terhadap Struktur Modal}

Berdasarkan data dan rumus maka perhitungan untuk perputaran modal kerja adalah sebagai berikut:

\section{Working Capital Turnover $=\frac{\text { Penjualan }}{\text { Aset Lancar }- \text { Utang Lancar }} \times 1$}

$$
\begin{aligned}
\text { WCT } 2014 & =\frac{4.208 .887}{939.720-499.174} \times 1 \\
& =933,37 \mathrm{kali}
\end{aligned}
$$

Tabel 1

Ringkasan Perputaran modal kerja Tahun 2014 s.d 2018

\begin{tabular}{|l|l|l|l|}
\hline Tahun & $\begin{array}{c}\text { Perputaran } \\
\text { Modal Kerja }\end{array}$ & Standar & Kriteria \\
\hline 2014 & 933 & $>3$ kali & Efisien \\
\hline 2015 & 2261 & $>3$ kali & Efisien \\
\hline 2016 & 911 & $>3$ kali & Efisien \\
\hline 2017 & 895 & $>3$ kali & Efisien \\
\hline 2018 & 930 & $>3$ kali & Efisien \\
\hline
\end{tabular}

Sumber: diolah peneliti, 2019

Hasil perhitungan tabel 1 di atas menunjukkan bahwa tingkat penjualan PT. Fast Food terus mengalami peningkatan didukung dengan perputaran modal kerja yang sangat tinggi tiap tahunnya. Berdasarkan standar kriteria tingkat efisiensi modal kerja, perputaran modal kerja perusahaan > 3 kali maka tingkat efisiensi perputaran modal kerja perusahaan tahun 2014 s.d tahun 2018 efisiensi. Tingginya 
tingkat efisiensi perputaran modal kerja dapat mengoptimalkan struktur modal perusahaan tanpa harus meningkatkan hutang. Penelitian ini sejalan dengan penelitian Aimi (2018) yang menyatakan bahwa pengelolaan modal kerja adalah serangkaian upaya yang dilakukan untuk menjaga dan mengatur aset lancar dan hutang lancar perusahaan agar tetap mampu memenuhi kebutuhan operasional.

\section{Analisis Ukuran Perusahaan terhadap Struktur Modal}

Berdasarkan data dan rumus maka perhitungan untuk ukuran perusahaan adalah sebagai berikut.

$$
\text { SIZE }=\text { Ln Total Aset }
$$

Tabel 2

Ringkasan Ukuran Perusahaan Tahun 2014 s.d 2018

\begin{tabular}{|c|l|}
\hline Tahun & \multicolumn{1}{|c|}{ Ukuran Perusahaan } \\
\hline 2014 & 2.162 .634 \\
\hline 2015 & 2.310 .536 \\
\hline 2016 & 2.577 .820 \\
\hline 2017 & 2.749 .422 \\
\hline 2018 & 2.989 .693 \\
\hline
\end{tabular}

Sumber: diolah peneliti, 2019

Hasil perhitungan tabel 2 di atas menunjukkan bahwa total aset perusahaan cukup baik. Total aset PT. Fast Food terus mengalami peningkatan signifikan tiap tahunnya. Penelitian ini sejalan dengan Alvareza dan Topowijono (2017) hasil penelitian menyatakan ukuran perusahaan berpengaruh signifikan terhadap struktur modal perusahaan Food dan Beverages yang terdaftar di BEI. Semakin tinggi nilai ukuran perusahaan maka semakin tinggi struktur modal perusahaan.

\section{Analisis Growth Opportunity terhadap Struktur Modal}

Berdasarkan data dan rumus maka perhitungan untuk peluang tumbuh adalah sebagai berikut

$$
\begin{gathered}
\text { Growth Opportunity }= \\
\frac{\text { Sales } t-\text { Sales } t-1}{\text { Sales } t-1} \times \mathbf{1 0 0} \%
\end{gathered}
$$

Tabel 3

Ringkasan Growth Opportunity Tahun 2014 s.d 2018

\begin{tabular}{|c|l|l|}
\hline Tahun & \multicolumn{1}{|c|}{ Sales } & \multicolumn{1}{|c|}{$\begin{array}{c}\text { Growth } \\
\text { Opportunity }\end{array}$} \\
\hline 2014 & 4.208 .887 & 7.112 .526 \\
\hline 2015 & 4.475 .061 & 1.647 .938 \\
\hline 2016 & 4.882 .307 & 465.533 \\
\hline 2017 & 5.302 .682 & 2.667 .31 \\
\hline 2018 & 6.017 .492 & $930.664,7$ \\
\hline
\end{tabular}

Sumber: diolah peneliti, 2019

Hasil perhitungan tabel 3 di atas menunjukkan bahwa tingkat penjualan PT. Fast Food mengalami peingkatan tiap tahunnya meskipun penjualan mengalami peningkatan. Hal ini menunjukkan rendahnya growth opportunity perusahaan dapat bermakna bahwa perusahaan tersebut tidak memiliki fleksiblilitas dalam melakukan investasi secara optimal yang dikarenakan manajer perusahaan akan melakukan tindakan pengalihan kemakmuran dari kreditur kepada investor, sehingga diharapkan perusahaan tersebut 
memiliki utang yang rendah. Perusahaan dengan prospek pertumbuhan besar harus menyediakan modal yang dapat mencukupi semua biaya yang keluar dari operasional perusahaan. Perusahaan dengan prospek pertumbuhan kecil menggunakan lebih banyak utang karena perusahaan tersebut akan membutuhkan dana yang besar untuk tumbuh dan mengembangkan usahanya yang tidak dapat dipenuhi semuanya melalui modal sendiri. Penelitian ini sejalan dengan penelitian Meutia (2016) menyatakan bahwa semakin tinggi Growth Opportunity maka semakin tinggi struktur modal perusahaan, begitupun sebaliknya.

\section{Analisis Profitabilitas terhadap Struktur Modal}

Berdasarkan data dan rumus maka perhitungan untuk peluang tumbuh adalah sebagai berikut:

$$
\text { ROA }=\frac{\text { Laba Setelah Pajak }}{\text { Total Aset }} \times 100 \%
$$

\section{Tabel 4}

\section{Ringkasan tingkat Profitabilitas}

Perusahaan Tahun 2014 s.d 2018

\begin{tabular}{|c|c|c|c|}
\hline Tahun & $\begin{array}{c}\text { Laba } \\
\text { setelah } \\
\text { Pajak }\end{array}$ & $\begin{array}{c}\text { Total } \\
\text { Aset }\end{array}$ & ROE \\
\hline 2014 & 125.952 & 2.162 .634 & $5,82 \%$ \\
\hline 2015 & 123.706 & 2.310 .536 & $5,35 \%$ \\
\hline 2016 & 148.196 & 2.577 .820 & $5,74 \%$ \\
\hline 2017 & 120.238 & 2.749 .422 & $4,37 \%$ \\
\hline 2018 & 296.801 & 2.989 .693 & $9,92 \%$ \\
\hline
\end{tabular}

Sumber: Hasil data diolah, 2019
Dari Tabel 4 diatas dapat dilihat tingkat laba perusahaan cukup fluktuatif dan meningkat signifikan pada tahun 2018. Tahun 2014 ke 2015 menurun sebesar 4,7\%, selanjutnya pada tahun 2016 meningkat sebesar 3,9\% dan tahun 2016 menurun sebesar $1,37 \%$ dan tahun 2018 mengalami peningkatan laba drastis sebesar 5,55\%. Penelitian ini sejalan dengan penelitian Dewi dan Sudiartha (2017) yang menyatakan bahwa profitabilitas dapat meningkatkan struktur modal perusahaan, semakin tinggi profitabilitas perusahaan maka makin optimal struktur modal untuk dikelola.

\section{Penutup}

Dari hasil penelitian dan pembahasan di atas dapat disimpulkan bahwa berdasarkan standar kriteria tingkat efisiensi nmodal kerja, perputaran modal kerja perusahaan > 3 kali maka tingkat efisiensi perputaran modal kerja perusahaan tahun 2014 s.d tahun 2018 efisiensi. Size perusahaan baik dapat dilihat dari nilai total aset perusahaan cukup baik. Total aset PT. Fast Food terus mengalami peningkatan signifikan tiap tahunnya. Growth opportunity PT. Fast Food mengalami penurunan tiap tahunnya meskipun penjualan mengalami peningkatan. Hal ini menunjukkan rendahnya growth opportunity perusahaan dapat bermakna bahwa perusahaan tersebut tidak memiliki fleksiblilitas dalam melakukan investasi secara optimal yang dikarenakan manajer perusahaan akan melakukan tindakan pengalihan kemakmuran dari kreditur kepada investor, sehingga diharapkan perusahaan tersebut memiliki utang yang rendah. Tingkat profitabilitas dapat diukur dari tingkat laba 
perusahaan cukup fluktuatif dan meningkat signifikan pada tahun 2018. Tahun 2014 ke 2015 menurun sebesar 4,7\%, selanjutnya pada tahun 2016 meningkat sebesar 3,9\% dan tahun 2016 menurun sebesar 1,37\% dan tahun 2018 mengalami peningkatan laba drastis sebesar 5,55\%.

\section{Daftar Pustaka}

Aimi, Lainil \& Topowijono, Ari Darmawan. 2018. Analisis Efisiensi Pengelolaan Modal Kerja dalam Hubungannya dengan Profitabilitas Perusahaan (Studi Pada Perusahaan Sub Sektor Kosmetik Dan Keperluan Rumah Tangga Yang Terdaftar Di Bursa Efek Indonesia Periode 2014-2016). Jurnal Administrasi Bisnis (JAB)|Vol. 58 No. 1 Mei 2018. Hal: 46-55

Astohar dan Setiawan, A. 2009, Analisis Pengaruh Ukuran (Size), Capital Adequacy Ratio (CAR), pertumbuhan Deposit, Loan to Deposit Ratio (LDR) terhadap Profitabilitas Perbankan Go Public di Indonesia tahun 2002-2005, Vol. No, 2009.

Brigham, Eugene F. \& Joel F. Houston. 2011. Dasar-Dasar Manajemen Keuangan. Edisi 10. Buku 1. Jakarta: Salemba Empat

Dewi, Dewa Ayu \& Sudiartha, Mertha. 2017. Pengaruh Profitabilitas, Ukuran Perusahaan dan Pertumbuhan Aset terhadap Struktur Modal dan Nilai Perusahaan. EJurnal Manajemen Unud Vol.6 (4) hal:2022-2252

Fahmi, Irham 2014. Analisa Kinerja Keuangan. Bandung Alfabeta

Husnan, Suad. 2011. Dasar-Dasar Teori Portofolio dan Analisis Sekuritas. AMP. YPKN, Yogyakarta
Halim, Abdul. 2015. Manajemen Keuangan Bisnis: Konsep dan Aplikasinya. Jakarta: Mitra Wacana Media.

Hanafi, Mamduh M. 2004. Manajemen Keuangan. Yogyakarta : Penerbit BPFEHalim. 2015

Jumingan. 2011. Analisis Laporan Keuangan. Jakarta: PT Bumi Aksara

Kasmir. 2010. Pengantar Manajemen Keuangan. Jakarta : Prenamedia Group

Munawir. 2013. Analisa Laporan Keuangan Edisi 4. Yogyakarta: Liberty.Munawir. 2013.

Riyanto, Bambang. 2002. Dasar-Dasar Pembelajaran Perusahaan. Edisi 4. Cetakan 1. Yogjakarta: BPFE. Sartono, Agus. 2001. Manajemen Keuangan: Teori dan Aplikasi. Edisi Keempat. Cetakan Pertama. Yogyakarta: BPFE.

Sawir, Agnes. 2005. Analisis Kinerja Keuangan dan Perencanaan Keuangan Perusahaan. Jakarta: PT. Gramedia Pustaka Utama

Sartono, R. Agus. 2010. Manajemen Keuangan Teori dan Aplikasi. Yogyakarta : BPFE

Tuti Meutia. 2016. Pengaruh Growth Opportunity, Profitabilitas dan Ukuran Perusahaan terhadap Struktur Modal pada Perusahaan Properti di BEI. Jurnal Manajemen dan Keuangan Vol 5(2) hal: 603-614

Utari, D., Purwanti A., dan Darsono Prawironegoro. 2014. Manajemen Keuangan. Jakarta: Mitra Wacana Media 